Article

\title{
Benzoxazole-Based Metal Complexes to Reverse Multidrug Resistance in Bacteria
}

\author{
Annamária Kincses ${ }^{1, * \mathbb{D}}$, Stefánia Szabó ${ }^{1}$, Bálint Rácz ${ }^{1}$, Nikoletta Szemerédi ${ }^{1}$, \\ Genki Watanabe ${ }^{2}$, Ryosuke Saijo ${ }^{2}{ }^{\circledR}$, Hiroshi Sekiya ${ }^{3}$, Eiji Tamai ${ }^{3}{ }^{\circledR}$, Joseph Molnár ${ }^{1}$, \\ Masami Kawase ${ }^{2}$ and Gabriella Spengler ${ }^{1}$ D \\ 1 Department of Medical Microbiology and Immunobiology, Faculty of Medicine, University of Szeged, \\ Dóm tér 10, H-6720 Szeged, Hungary; stefiszabo@gmail.com (S.S.); balintracz95@gmail.com (B.R.); \\ szemeredi.nikoletta@med.u-szeged.hu (N.S.); molnar.jozsef@med.u-szeged.hu (J.M.); \\ spengler.gabriella@med.u-szeged.hu (G.S.) \\ 2 College of Pharmaceutical Sciences, Matsuyama University, 4-2 Bunkyo-cho, Matsuyama 790-8578, Japan; \\ gykks333w@icloud.com (G.W.); rsaijo@g.matsuyama-u.ac.jp (R.S.); kawase@g.matsuyama-u.ac.jp (M.K.) \\ 3 Department of Infectious Diseases, College of Pharmaceutical Sciences, Matsuyama University, \\ 4-2 Bunkyo-cho, Matsuyama 790-8578, Japan; hsekiya@g.matsuyama-u.ac.jp (H.S.); \\ etamai@g.matsuyama-u.ac.jp (E.T.) \\ * Correspondence: kincses.annamaria@med.u-szeged.hu
}

Received: 30 August 2020; Accepted: 25 September 2020; Published: 28 September 2020

\begin{abstract}
Bacteria often show resistance against antibiotics due to various mechanisms such as the expression of efflux pumps, biofilm formation, or bacterial quorum sensing (QS) controls. For successful therapy, the discovery of alternative agents is crucial. The objective of this study was to evaluate the efflux pump, anti-biofilm, and QS inhibiting, as well as antibacterial effects of 2-trifluoroacetonylbenzoxazole ligands (1-3) and their metal complexes (4-12) in bacteria. The ligand 2 and its $\mathrm{Zn}$ (II) complex 5, and furthermore the $\mathrm{Cu}(\mathrm{II})$ complex 7 of ligand 1, exerted remarkable antibacterial activity on the Staphylococcus aureus 272123 (MRSA) strain. In the minimum inhibitory concentration (MIC) reduction assay the ligand 3 , the $\mathrm{Zn}$ (II) complex 5 of ligand $\mathbf{2}$, and the $\mathrm{Cu}(\mathrm{II}), \mathrm{Ni}(\mathrm{II})$, $\mathrm{Mg}(\mathrm{II}), \mathrm{Fe}(\mathrm{III})$ complexes $(\mathbf{7}, \mathbf{8}, \mathbf{9}, \mathbf{1 2})$ of ligand 1 enhanced the antibacterial activity of ciprofloxacin in MRSA. An increased ethidium bromide accumulation was detected for ligand 3 in MRSA while the Fe(III) complex 12 of ligand 1 decreased the biofilm formation of the reference $S$. aureus ATCC 25923 strain. The $\mathrm{Zn}$ (II) and $\mathrm{Ag}$ (II) complexes (3 and $\mathbf{4}$ ) of ligand $\mathbf{1}$ and ligand $\mathbf{3}$ inhibited the QS. Based on our results, the ligands and their metal complexes could be potential alternative drugs in the treatment of infectious diseases.
\end{abstract}

Keywords: E. coli; Staphylococcus aureus; multidrug resistance; benzoxazole skeleton; metal complexes; efflux pump; biofilm

\section{Introduction}

Antimicrobial resistance is one of the greatest concerns of public health worldwide since drug-resistant bacterial infections have increased risk of worse clinical outcomes and death. The infection caused by resistant bacteria results in lengthier stays in hospital and may need more intensive care or more expensive drugs [1]. Antibacterial resistance can come from various mechanisms, including enzymatic degradation of antibiotics, alteration of antibiotic targets, blocking of drug entry, and increasing expression of efflux pumps (EPs) [2].

EPs play a significant role in bacteria; six different families of EP systems enable bacteria to extrude various potentially toxic substances such as antibiotics, heavy metals, organic pollutants, 
and plant-produced compounds. Among these families we can differentiate: ATP-binding cassette (ABC) transporters, multidrug and toxic compound extrusion (MATE) transporters, small multidrug resistance (SMR) transporters, major facilitator superfamily (MFS) transporters, resistance nodulation cell division (RND) transporters, and proteobacterial antimicrobial compound efflux (PACE) transporters [3]. MFS and MATE transporters are expressed mainly by Gram-positive bacteria, while RND transporters are found almost exclusively in Gram-negative bacteria [4]. The most investigated RND efflux system is AcrAB-TolC, which constitutes the AcrB RND EP, TolC outer membrane protein, and AcrA serves as periplasmic adaptor protein [5].

The formation of biofilms gives rise to many clinical problems and plays a role in antibacterial resistance. Biofilm is a dynamic structure built by multicellular bacterial community and its extracellular polymeric matrix. This environment not only provides bacteria with protection against drugs, host immune attacks, and environmental stresses, but also forms a platform of metabolic exchange and cellular communication [6].

Quorum sensing (QS) is a cell-cell communication system enabling bacteria to regulate gene expression based on cell population density [7]. Though QS bacteria can alter their phenotypes and behaviors, they may be able to form biofilms and express various virulence factors (such as EPs) resulting in an enhanced drug resistance [8].

Metal complexes are already widely used in clinical settings and many antibiotics containing metal complexes have better pharmaceutical characteristics [9-11]. Benzoxazole skeleton-containing molecules are also in the scope of research due to their antimicrobial and antiproliferative properties [12-14]. The importance of benzoxazole core and 2-trifluoroacetonyl moiety of 2-trifluoroacetonylbenzoxazole 1 in order to express their antimicrobial activities has been previously highlighted [15-17]. In recent work on 2-trifluoroacetonylbenzoxazole ligand 1 for metal complexes, Zn(II) complex 4 of ligand 1 formed a stable six-membered ring in a bidentate mode to consist of 1 with $\mathrm{Zn}(\mathrm{II})$ ion in 2:1 ratio with good antibacterial activities against Gram-positive pathogens [18] and potent multidrug-resistance reversing activities in cancer cells [19]. In this article, we report the multidrug resistance-modulating activities of 2-trifluoroacetonylbenzoxazole ligands (1-3) and their metal complexes (4-12) in bacteria related to the inhibition of QS and biofilm formation.

\section{Results}

\subsection{Antibacterial Activity}

The antibacterial activity of 2-trifluoroacetonylbenzoxazole ligands and their metal complexes was tested on two Gram-positive (Staphylococcus aureus ATCC 25923 and S. aureus 272123 (MRSA), two Gram-negative (wild-type Escherichia coli AG100 expressing the AcrAB TolC EP at its basal level and its AcrAB-TolC deleted mutant E. coli AG100 A strain), and QS (Chromobacterium violaceum 026 and Enterobacter cloacae 31298) bacterial strains. Most compounds were effective against S. aureus and E. coli strains and the most potent effects were detected on the MRSA strain (Table 1).

The ligand 2 containing a $\mathrm{CF}_{2} \mathrm{Cl}$ moiety and its $\mathrm{Zn}(\mathrm{II})$ complex 5 furthermore $\mathrm{Cu}(\mathrm{II})$ complex $\mathbf{7}$ of ligand 1 had the strongest antibacterial activity (minimum inhibitory concentration (MIC): $3.125 \mu \mathrm{M}$ ) on S. aureus MRSA. The MIC value of ligand 3 containing a $\mathrm{CF}_{2} \mathrm{H}$ moiety was $50 \mu \mathrm{M}$, while its $\mathrm{Zn}$ (II) complex 6 exhibited an MIC of $12.5 \mu \mathrm{M}$ on the MRSA strain. Furthermore, ligand 1 showed an MIC of $12.5 \mu \mathrm{M}$; however, the ligand in $\mathrm{Cu}(\mathrm{II})$ complex 7 increased its activity, showing an MIC of $3.125 \mu \mathrm{M}$. In addition, the complexes of ligand 1 with $\mathrm{Zn} \mathrm{(4),} \mathrm{Ni}(8)$, and $\mathrm{Mg}(9)$ were also more effective than ligand 1 alone against MRSA. None of the compounds had any antibacterial effect on the $C$. violaceum and E. cloacae strains. The MIC of solvent dimethyl sulfoxide (DMSO) was $>1 \%$, and the concentration of DMSO applied in the assay had no antibacterial effect. 
Table 1. Minimum inhibitory concentrations (MICs) of the ligands and their metal complexes on Staphylococcus aureus ATCC 25923, S. aureus 272123, Escherichia coli AG100, E. coli AG100 A, Chromobacterium violaceum 026, and Enterobacter cloacae 31298.

\begin{tabular}{ccccccc}
\hline \multirow{2}{*}{ Compound } & \multicolumn{7}{c}{ MIC $(\mu \mathrm{M})$} \\
\cline { 2 - 7 } & $\begin{array}{c}\text { S. aureus } \\
\text { ATCC } 25923\end{array}$ & $\begin{array}{c}\text { S. aureus 272123 } \\
\text { (MRSA) }\end{array}$ & $\begin{array}{c}\text { E. coli } \\
\text { AG100 }\end{array}$ & $\begin{array}{c}\text { E. coli } \\
\text { AG100 A }\end{array}$ & $\begin{array}{c}\text { C. violaceum } \\
\mathbf{0 2 6}\end{array}$ & $\begin{array}{c}\text { E. cloacae } \\
\mathbf{3 1 2 9 8}\end{array}$ \\
\hline $\mathbf{1}$ & 25 & 12.5 & 50 & 50 & $>100$ & $>100$ \\
$\mathbf{2}$ & 12.5 & 3.125 & 50 & 25 & $>100$ & $>100$ \\
$\mathbf{3}$ & 100 & 50 & 50 & 25 & $>100$ & $>100$ \\
$\mathbf{4}$ & 12.5 & 6.25 & 25 & 25 & $>100$ & $>100$ \\
$\mathbf{5}$ & 12.5 & 3.125 & 50 & 12.5 & $>100$ & $>100$ \\
$\mathbf{6}$ & 25 & 12.5 & 50 & 12.5 & $>100$ & $>100$ \\
$\mathbf{7}$ & 12.5 & 3.125 & $>100$ & 12.5 & $>100$ & $>100$ \\
$\mathbf{8}$ & 25 & 6.25 & 50 & 25 & $>100$ & $>100$ \\
$\mathbf{9}$ & 25 & 6.25 & 50 & 25 & $>100$ & $>100$ \\
$\mathbf{1 0}$ & $>100$ & $>100$ & $>100$ & $>100$ & $>100$ & $>100$ \\
$\mathbf{1 1}$ & 25 & 12.5 & 25 & 50 & $>100$ & $>100$ \\
$\mathbf{1 2}$ & 50 & 25 & $>100$ & 50 & $>100$ & $>100$ \\
\hline
\end{tabular}

\subsection{Resistance Modulation Assay}

The resistance modulation effects of compounds with ciprofloxacin (CIP) and tetracycline (TET) antibiotics were evaluated by the MIC reduction method on the Gram-negative E. coli AG100, AG100 A, and the Gram-positive $S$. aureus ATCC and MRSA strains. In the absence of the compounds, the MIC value of CIP was $12.5 \mu \mathrm{M}$ on MRSA and $0.016 \mu \mathrm{M}$ on E. coli AG100. Ligand 3, the Zn(II) complex 5 of ligand 2, and the complex of ligand 1 with $\mathrm{Cu}(7), \mathrm{Ni}(8), \mathrm{Mg}(9)$, and $\mathrm{Fe}$ (12) showed synergism with CIP: these compounds applied at a quarter of the MIC reduced the MIC value of CIP by 2 -fold $(6.25 \mu \mathrm{M})$ on MRSA (Table 2).

Table 2. Minimum inhibitory concentration (MIC) of ciprofloxacin (CIP) in combination with compounds in Staphylococcus aureus MRSA 272123 and E. coli AG100.

\begin{tabular}{ccc}
\hline \multirow{2}{*}{ Compound $^{1}$} & \multicolumn{2}{c}{ CIP $_{\text {MIC }}(\mu \mathrm{M})$ Combination with Compounds } \\
\cline { 2 - 3 } & S. aureus MRSA & E. coli AG100 \\
\hline $\mathbf{3}$ & 6.25 & 0.016 \\
$\mathbf{5}$ & 6.25 & 0.016 \\
$\mathbf{7}$ & 6.25 & 0.016 \\
$\mathbf{8}$ & 6.25 & 0.008 \\
$\mathbf{9}$ & 6.25 & 0.008 \\
$\mathbf{1 2}$ & 6.25 & 0.016 \\
\hline CIP $_{\text {MIC }}$ & 12.5 & 0.016 \\
\hline \multicolumn{4}{c}{${ }^{1}$ The concentration of compounds was $\frac{1}{4}$ MIC. }
\end{tabular}

The $\mathrm{Ni}(\mathrm{II})$ and $\mathrm{Mg}$ (II) complexes (8 and $\mathbf{9})$ of ligand 1 were able to decrease the MIC of CIP, resulting in a 2-fold reduction on E. coli AG100 (Table 2). None of the compounds could modulate the MIC of TET on the strains investigated; furthermore, the compounds were not able to improve the activity of CIP on the reference S. aureus ATCC and E. coli AG100 A strains (data not shown).

\subsection{Efflux Pump Inhibiting Activity}

Since multidrug resistance EPs are very important factors contributing to multidrug resistance (MDR) in both Gram-positive and Gram-negative bacteria, the inhibition of these pumps could reverse the resistant phenotype and restore the activity of antibiotics. The effect of compounds on ethidium bromide (EB) accumulation was determined by the automated EB method. This assay was used to determine how much of the fluorescent dye and pump substrate EB was accumulated by the bacterial cells in the presence of the tested compounds. The real-time accumulation of EB was monitored for 
$30 \mathrm{~min}$ in both $S$. aureus and E. coli strains. Ligand 3 was a potent EP inhibitor (relative fluorescence index or RFI: 0.13 ) at $12.5 \mu \mathrm{M}$ compared to the positive control verapamil (VER) (RFI: 0.14 ) at $25 \mu \mathrm{M}$ in MRSA; on the other hand, the other ligands and complexes had no effect on the intracellular EB accumulation in both $S$. aureus and E. coli AG100 A strains (Table 3).

Table 3. Relative fluorescence index (RFI) of tested compounds on Staphylococcus aureus ATCC 25923, S. aureus MRSA 272123, E. coli AG100, and E. coli AG100 A.

\begin{tabular}{ccccc}
\hline \multirow{2}{*}{ Compound } & \multicolumn{4}{c}{ RFI } \\
\cline { 2 - 5 } & $\begin{array}{c}\text { S. aureus ATCC } \\
\mathbf{2 5 9 2 3}\end{array}$ & $\begin{array}{c}\text { S. aureus 272123 } \\
\text { (MRSA) }\end{array}$ & E. coli AG100 & E. coli AG100 A \\
\hline $\mathbf{1}$ & -0.11 & -0.14 & -0.35 & 0 \\
$\mathbf{2}$ & -0.07 & -0.07 & 0.17 & -0.01 \\
$\mathbf{3}$ & -0.01 & $\mathbf{0 . 1 3}$ & -0.07 & -0.03 \\
$\mathbf{4}$ & -0.03 & -0.11 & -0.10 & -0.17 \\
$\mathbf{5}$ & 0.03 & -0.13 & $\mathbf{0 . 3 7}$ & -0.19 \\
$\mathbf{6}$ & 0.08 & -0.02 & 0.08 & -0.15 \\
$\mathbf{7}$ & 0.12 & -0.01 & -0.06 & 0.11 \\
$\mathbf{8}$ & -0.20 & -0.01 & 0.11 & -0.15 \\
$\mathbf{9}$ & -0.10 & -0.01 & -0.01 & -0.03 \\
$\mathbf{1 0}$ & 0 & 0 & -0.06 & 0 \\
$\mathbf{1 1}$ & 0.11 & -0.11 & $\mathbf{0 . 3 7}$ & 0.12 \\
$\mathbf{1 2}$ & -0.02 & -0.02 & 0.04 & 0.09 \\
CPZ & 0.17 & - & 0.38 & 0.48 \\
VER & - & 0.14 & - & - \\
\hline
\end{tabular}

${ }^{1}$ Chlorpromazine; ${ }^{2}$ verapamil. The active compounds are presented in bold.

However, the $\mathrm{Zn}(\mathrm{II})$ complex 5 of the ligand 2 (RFI: 0.37) and the $\mathrm{Ag}(\mathrm{I})$ complex 11 of ligand 1 (RFI: 0.37) compared with the positive control chlorpromazine (CPZ) (RFI: 0.38), exhibited remarkable inhibition on the AcrAB-TolC in E. coli AG100. The other compounds had no activity on the intracellular EB accumulation by E. coli AG100 (Table 3).

\subsection{Anti-Biofilm Activity}

The effect of ligands and their metal complexes on biofilm formation was evaluated on the reference S. aureus ATCC 25923 strain. The biofilm inhibition (\%) was calculated based on the mean of absorbance units. The decrease of biofilm formation was calculated in comparison to the untreated biofilm mass and the percentage of inhibition was calculated based on these data, the level of significance was $p<0.001$. As shown in Figure 1, the ligand 3 and the Fe(III) complex 12 of ligand 1 exhibited biofilm inhibition of 16.4 and $75 \%$, respectively.

\subsection{Inhibition of Quorum Sensing}

As shown in Table 4, the most remarkable inhibition of quorum sensing was exerted by ligand 3 (inhibition zone: $56 \mathrm{~mm}$ ) and the $\mathrm{Ag}(\mathrm{I})$ complex 11 of ligand 1 followed by the $\mathrm{Zn}(\mathrm{II})$ complex 4 of ligand 1 (inhibition zone: $47 \mathrm{~mm}$ ). In addition, the $\mathrm{Zn}(\mathrm{II})$ complex $\mathbf{5}$ of ligand 2 exerted a similar anti-QS effect to the positive control promethazine (PMZ), leading to the decrease of violacein production. The other ligand alone and the other metal complexes did not possess any effects to inhibit the bacterial communication (inhibition zone: $0 \mathrm{~mm}$; data not shown). 


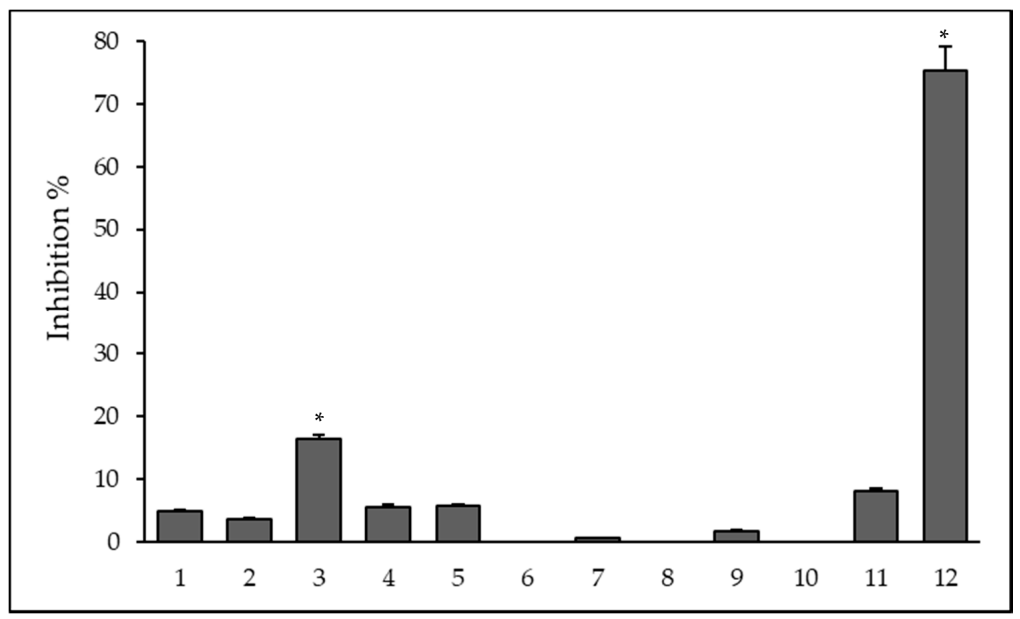

Figure 1. Anti-biofilm effect of ligands and their metal complexes on Staphylococcus aureus ATCC 25923 at $\frac{1}{4}$ MIC. The level of significance was ${ }^{*} p<0.001$.

Table 4. The quorum sensing inhibitory effect of the active compounds and the positive control promethazine (PMZ).

\begin{tabular}{ccc}
\hline Compound & Inhibition Zone in $\mathbf{~ m m}$ & SD $^{\mathbf{1}}( \pm)$ \\
\hline $\mathbf{3}$ & 56 & 3.3 \\
$\mathbf{4}$ & 47 & 2.1 \\
$\mathbf{5}$ & 16 & 0.9 \\
$\mathbf{1 1}$ & 53 & 1.4 \\
$\mathbf{P M Z}$ & 16 & 1.8 \\
\hline \multicolumn{3}{c}{}
\end{tabular}

\subsection{Cytotoxic Effect on Human Cell Line}

The toxic effect of ligands and their metal complexes were tested on the MRC-5 human embryonal lung fibroblast cell line by cytotoxicity assay. $\mathrm{Zn}(\mathrm{II})$ and $\mathrm{Ni}(\mathrm{II})$ complexes (4 and 8) of ligand 1, $\mathrm{Zn}$ (II) complex 5 of ligand 2, and the $\mathrm{Zn}$ (II) complex $\mathbf{6}$ of ligand 3 had a strong cytotoxic effect on human cells ( $\mathrm{IC}_{50}$ between 4.72 and $24.57 \mu \mathrm{M}$ ). Ligand 3 alone presented moderate inhibitory activity; the $\mathrm{IC}_{50}$ value was $44.45 \mu \mathrm{M}$. The complex of ligand 1 with $\mathrm{Cu}(\mathbf{7}), \mathrm{Pd}(\mathbf{1 0})$, and $\mathrm{Ag}(\mathbf{1 1})$ showed weak cytotoxic activity on MRC-5. Fortunately, ligand 1 alone and its complexes with $\mathrm{Mg}$ (9), Fe (12), and furthermore ligand 2, had no toxic effect on normal cells: Their $\mathrm{IC}_{50}$ values were $>100 \mu \mathrm{M}$ (Table 5).

Table 5. Cytotoxic activity of tested compounds against MRC-5 human embryonal lung fibroblast cell line.

\begin{tabular}{ccc}
\hline \multirow{2}{*}{ Compounds } & \multicolumn{2}{c}{ MRC-5 } \\
\cline { 2 - 3 } & $\mathrm{IC}_{\mathbf{5 0}}{ }^{\mathbf{1}}(\boldsymbol{\mu} \mathbf{M})$ & $\mathrm{SD}^{\mathbf{2}}( \pm)$ \\
\hline $\mathbf{1}$ & $>100$ & - \\
$\mathbf{2}$ & $>100$ & - \\
$\mathbf{3}$ & 44.45 & 2.72 \\
$\mathbf{4}$ & 17.47 & 4.82 \\
$\mathbf{5}$ & 24.57 & 1.42 \\
$\mathbf{6}$ & 4.72 & 0.01 \\
$\mathbf{7}$ & 76.10 & 0.89 \\
$\mathbf{8}$ & 12.24 & 0.62 \\
$\mathbf{9}$ & $>100$ & - \\
$\mathbf{1 0}$ & 89.11 & 6.02 \\
$\mathbf{1 1}$ & 65.89 & 3.8 \\
$\mathbf{1 2}$ & $>100$ & - \\
\hline
\end{tabular}

${ }^{1}$ Inhibitory concentration $50 ;{ }^{2}$ standard deviation. 


\section{Discussion}

Metal complexes could provide a beneficial tool for pharmaceuticals and there have been several compounds with anticancer, antimalarial, and anti-neurodegenerative activities in clinical trials. However, metal complexes as potential antibacterial agents gained less attention until now, despite the fact that they possess remarkable antimicrobial effects [20]. Based on our results, the antibacterial effect of 2-fluoroacetonylbenzoxazole ligands could be increased by metal-based coordination complexes of these ligands. The metal complexes could be applied to reduce the virulence of bacteria (inhibition of QS and biofilm formation) and restore the sensitivity of multidrug resistant bacteria by modulating the overexpressed EP systems, and they could be administered together with antibiotics to improve the efficacy of antibacterial therapy.

As shown previously, transition metal complexes can demonstrate better antimicrobial activity than the ligands themselves. 2-substituted benzoxazoles are important scaffolds because they possess antimicrobial, antiviral, antifungal, and anticancer effects as well [18].

Based on the results, it has been confirmed that the metal complexes exerted more pronounced antibacterial activity than the ligands: This tendency was observed in the case of the complexes of the 2-trifluoroacetonylbenzoxazole ligand 1 with $\mathrm{Zn}(\mathrm{II}), \mathrm{Cu}(\mathrm{II}), \mathrm{Ni}(\mathrm{II}), \mathrm{Mg}(\mathrm{II})$, and, furthermore, in the case of the complex of the ligand 3 with $\mathrm{Zn}(\mathrm{II})$ on the Gram-positive S. aureus MRSA and reference ATCC strains. However, ligand 2 and with $\mathrm{Zn}(\mathrm{II})$, furthermore, ligand $\mathbf{1}$ with $\mathrm{Cu}(\mathrm{II})$, had a more potent antibacterial effect (MIC: $3.125 \mu \mathrm{M}$ ) than the reference standard TET (MIC: $6.25 \mu \mathrm{M})$ or CIP (MIC: $12.5 \mu \mathrm{M}$ ) on the $S$. aureus MRSA strain. Ligand 1 with $\mathrm{Zn}(\mathrm{II}), \mathrm{Ni}(\mathrm{II})$, and $\mathrm{Mg}(\mathrm{II})$ were more effective (MIC: $6.25 \mu \mathrm{M}$ ) compared to CIP against S. aureus MRSA. The MIC of TET was $50 \mu \mathrm{M}$ on E. coli AG100, but stronger growth inhibition was observed for ligand 1 with $\mathrm{Zn}(\mathrm{II})$ and Ag(II); MIC was $25 \mu \mathrm{M}$.

In three ligands $\mathbf{1}-\mathbf{3}$, the order of antibacterial potency was $\mathbf{2}>\mathbf{1}>\mathbf{3}$. Interestingly, ligand 3 with the lowest antibacterial activity could potentiate the activity of CIP on MRSA strain. The other ligands $\mathbf{1}$ and $\mathbf{2}$ could show the same activity in the form of metal complexes: the Zn(II) complex $\mathbf{5}$ of ligand $\mathbf{2}$ and the complexes of ligand 1 with $\mathrm{Cu}(7), \mathrm{Ni}(\mathbf{8}), \mathrm{Mg}(\mathbf{9})$, and $\mathrm{Fe}(\mathbf{1 2})$. In addition, complexes 8 and 9 were effective in combination with CIP on E. coli AG100 as well.

In order to re-sensitize antibiotic-resistant bacteria, EP inhibitors could be used to overcome the resistant phenotype. Ligand 3 was a potent EP inhibitor on MRSA but had no activity on the sensitive S. aureus reference strain and the Gram-negative E. coli AG100 expressing the AcrAB-TolC efflux system. The reason for that is the different cell wall composition, because Gram-positives have a thick layer of peptidoglycan, and in the case of MRSA isolate, the distribution of essential proteins involved in lipid metabolism, and the expression of EPs and membrane proteins may be different compared to sensitive ATCC isolates [21]. On the contrary, Gram-negatives possess a thin peptidoglycan layer, but because of the presence of the inner and outer membranes, tripartite efflux pump systems such as the AcrAB-TolC system can be overexpressed in resistant Gram-negative isolates. The Zn(II) complex 5 of ligand 2 and the $\mathrm{Ag}(\mathrm{II})$ complex 11 of ligand $\mathbf{1}$ inhibited the AcrAB-TolC efflux system in E. coli AG100, and these complexes exhibited moderate toxicity on normal MRC-5 human embryonal fibroblast cells (IC 50 of $24.57 \mu \mathrm{M}$ and $65.89 \mu \mathrm{M}$, respectively). According to previous studies [18], the Ag(II) complex 11 was found to exhibit the strongest inhibitory activity against various Gram-negative bacteria, especially against Pseudomonas aeruginosa, causing membrane permeabilization and degradation.

The bacterial virulence can be reduced if the bacterial communication and the virulence factors related to QS can be inhibited. The bacterial communication could be hampered by treatment with ligand 3, the $\mathrm{Ag}$ (II) complex 11 of ligand 1, and the $\mathrm{Zn}$ (II) complexes 4 and 5 of ligand 1 and 2, respectively; however, the nature of the interaction between QS molecules and benzoxazole-based compounds needs further investigation. The QS-related process is the biofilm formation whereby microorganisms irreversibly attach to and grow on a surface and produce extracellular polymers that facilitate attachment and matrix formation, resulting in increased resistance towards antibiotic treatment. The most pronounced anti-biofilm activity was found in case of the Fe(III) complex 12 of ligand 1 on reference $S$. aureus and this complex had no toxicity on normal human fibroblast 
cells. Regarding antibacterial activity of the metal complexes, there were multiple modes of action. They could undergo ligand exchange reactions, release bioactive molecules, or be triggered by light irradiation to generate reactive oxygen species (ROS). However, complexes 4-12, except the $\mathrm{Ag}(\mathrm{I})$ complex 11, were fairly stable against air and moisture because the ligands 1-3 can possess a heteroaryl-substituted alkenol ligand system and act as the $\mathrm{N}, \mathrm{O}$-chelating ligand, producing highly stable metal complexes, which could be reinforced by a positive inductive effect of the heterocyclic moiety and a negative inductive effect of the $\mathrm{CF}_{3}$ group [18]. For example, $\mathrm{Zn}(\mathrm{II})$ complex 6 was inert to excess ethylenediaminetetraacetic acid (EDTA) at room temperature [18]. Therefore, these metal complexes may be stable in vivo. The increased potency on complexation of ligands with metals can be explained by the enhancement of the penetration into the lipid membranes due to the increased lipophilicity of the complexes [22,23].

Based on preliminary results, all compounds except $\mathrm{Pd}(\mathrm{II})$ complex 10 showed higher toxicity $\left(\mathrm{IC}_{50}: 0.5-10.99 \mu \mathrm{M}\right)$ against MDR mouse T-cell lymphoma cells than chemotherapeutic drug cisplatin $\left(\mathrm{IC}_{50}: 11.20 \mu \mathrm{M}\right)$ used as reference compound [19]. The present data demonstrated that $\mathrm{Zn}$ (II) complexes 4, 5, 6, and $\mathrm{Ni}$ (II) complex 8 had a stronger inhibitory effect on MRC-5 human embryonic lung fibroblast cell line compared to the activity of cisplatin $\left(\mathrm{IC}_{50}: 33.45 \mu \mathrm{M}\right)[24]$ on the same cell line.

\section{Materials and Methods}

\subsection{Compounds}

The synthesis of three 2-trifluoroacetonylbenzoxazole ligands and their metal complexes $(\mathrm{Zn}, \mathrm{Cu}$, $\mathrm{Ni}, \mathrm{Mg}$, Pd, and Ag) was described previously [18] (Table 6). The Fe(III) complex 12 was obtained by the reaction of $\mathbf{1}$ with $\mathrm{FeCl}_{3}$ using the same method described for the preparation of $\mathbf{4}$ [18]. The compounds (1-12) screened for their antibacterial, MDR-modulating, anti-biofilm, and QS inhibition activities, furthermore, they were investigated in combination with antibiotics. The powdered compounds were dissolved in DMSO and stock solutions of $10 \mathrm{mM}$ were prepared. The preparation was performed by vortexing at room temperature.

Table 6. Structures of ligands and their metal complexes.

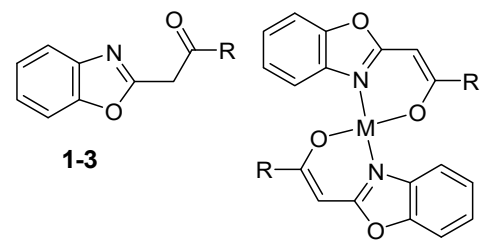

4-10

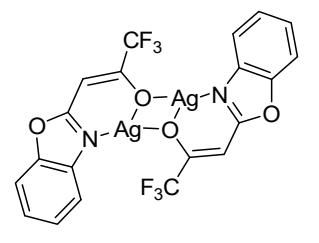

11

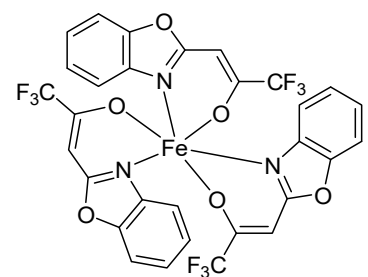

12

\begin{tabular}{ccccc}
\hline Compound & $\mathbf{R}$ & $\mathbf{M}$ & Structure & Molecular Weight \\
\hline $\mathbf{1}$ & $\mathrm{CF}_{3}$ & - & - & 229 \\
$\mathbf{2}$ & $\mathrm{CF}_{2} \mathrm{Cl}$ & - & - & 245.6 \\
$\mathbf{3}$ & $\mathrm{CF}_{2} \mathrm{H}$ & - & - & 211 \\
$\mathbf{4}$ & $\mathrm{CF}_{3}$ & $\mathrm{Zn}$ & $\mathrm{L}_{2} \mathrm{Zn}$ & 522 \\
$\mathbf{5}$ & $\mathrm{CF}_{2} \mathrm{Cl}$ & $\mathrm{Zn}$ & $\mathrm{L}_{2} \mathrm{Zn}$ & 554.6 \\
$\mathbf{6}$ & $\mathrm{CF}_{2} \mathrm{H}$ & $\mathrm{Zn}$ & $\mathrm{L}_{2} \mathrm{Zn}$ & 486 \\
$\mathbf{7}$ & $\mathrm{CF}_{3}$ & $\mathrm{Cu}$ & $\mathrm{L}_{2} \mathrm{Cu}$ & 520 \\
$\mathbf{8}$ & $\mathrm{CF}_{3}$ & $\mathrm{Ni}$ & $\mathrm{L}_{2} \mathrm{Ni}$ & $551\left(\right.$ apical $\left.2 \mathrm{H}_{2} \mathrm{O}\right)$ \\
$\mathbf{9}$ & $\mathrm{CF}_{3}$ & $\mathrm{Mg}$ & $\mathrm{L}_{2} \mathrm{Mg}$ & 481 \\
$\mathbf{1 0}$ & $\mathrm{CF}_{3}$ & $\mathrm{Pd}$ & $\mathrm{L}_{2} \mathrm{Pd}$ & 563 \\
$\mathbf{1 1}$ & $\mathrm{CF}_{3}$ & $\mathrm{Ag}$ & $\mathrm{L}_{2} \mathrm{Ag}$ & 672 \\
$\mathbf{1 2}$ & $\mathrm{CF}_{3}$ & $\mathrm{Fe}$ & $\mathrm{L}_{3} \mathrm{Fe}$ & 740 \\
\hline \multicolumn{5}{r}{}
\end{tabular}


PMZ, CPZ, crystal violet (CV), EB, VER, TET, CIP, Luria-Bertani (LB) broth, and LB agar were obtained from Sigma-Aldrich Chemie $\mathrm{GmbH}$ (Steinheim, Germany). The modified LB medium (LB*) consisted of yeast extract $5 \mathrm{~g} / \mathrm{L}$, tryptone $10 \mathrm{~g} / \mathrm{L}, \mathrm{NaCl} 10 \mathrm{~g} / \mathrm{L}, \mathrm{K}_{2} \mathrm{HPO}_{4} 1 \mathrm{~g} / \mathrm{L}, \mathrm{MgSO}_{4} \times 7 \mathrm{H}_{2} \mathrm{O} 0.3 \mathrm{~g} / \mathrm{L}$, and FeNaEDTA $36 \mathrm{mg} / \mathrm{L}$. To obtain modified LB* agar, the $\mathrm{LB}^{*}$ medium was enriched with agar $20 \mathrm{~g} / \mathrm{L}$ (Difco, Detroit, MI, USA). The pH was adjusted to 7.2. Tryptic soy broth (TSB), tryptic soy agar, and Mueller Hinton broth (MHB) were obtained from Scharlau Chemie S.A. (Barcelona, Spain). $\mathrm{CV}$ solution was prepared by adding $0.05 \mathrm{~g}$ of $\mathrm{CV}$ to $50 \mathrm{~mL}$ of distilled water, then the solution was filtered $(0.22 \mu \mathrm{M}$ filter).

\subsection{Bacterial Strains}

Wild-type E. coli K-12 AG100 strain (argE3 thi-1 rpsL xyl mtl $\Delta$ (gal-uvrB) supE44) expressing the AcrAB TolC EP at its basal level and its AcrAB-TolC deleted mutant E. coli K-12 AG100 A strain. The strains were donated by Prof. Dr. Hiroshi Nikaido (Department of Molecular and Cell Biology and Chemistry, University of California, Berkeley, CA, USA).

The compounds were further investigated against two Gram-positive strains, S. aureus ATCC 25923 (MSSA), used as the methicillin susceptible reference strain, and the methicillin- and ofloxacin-resistant S. aureus 272123 clinical isolate (MRSA), which was given by Prof. Dr. Leonard Amaral (Institute of Hygiene and Tropical Medicine, Lisbon, Portugal).

The following bacterial strains were applied in the QS tests: C. violaceum 026 as sensor strain and E. cloacae 31298 isolated from clinical wound (used as N-acyl-homoserine lactone (AHL) producer); this strain induced pigment production by C. violaceum and is a model strain to study QS interactions.

\subsection{Cell Culture}

The MRC-5 human embryonic lung fibroblast cell line (ATCC CCL-171; provider: LGC Promochem, Teddington, UK) was used in the experiments. The cells were cultivated in Eagle's Minimal Essential Medium (EMEM; Sigma-Aldrich, St. Louis, MO, USA), supplemented with $1 \%$ non-essential amino acid mixture, 10\% heat-inactivated fetal bovine serum, $2 \mathrm{mM}$ L-glutamine, $1 \mathrm{mM}$ Na-pyruvate, nystatin, and a penicillin-streptomycin mixture in concentrations of $100 \mathrm{U} / \mathrm{L}$ and $10 \mathrm{mg} / \mathrm{L}$, respectively. The supplementary components were obtained from Sigma-Aldrich, St. Louis, MO, USA. The cell culture was kept in a humidified atmosphere $\left(5 \% \mathrm{CO}_{2}, 95 \%\right.$ air $)$ at $37^{\circ} \mathrm{C}$.

\subsection{Determination of Minimum Inhibitory Concentrations}

The minimum inhibitory concentrations (MICs) of compounds were determined in 96-well plates based on the Clinical and Laboratory Standard Institute guidelines (CLSI guidelines) [25]. The compounds were diluted in $100 \mu \mathrm{L}$ of MHB. Then, $10^{-4}$ dilution of an overnight bacterial culture in $100 \mu \mathrm{L}$ of medium were added to each well, with the exception of the medium control wells. The plates were further incubated at $37^{\circ} \mathrm{C}$ for $18 \mathrm{~h}$; at the end of the incubation period, the MIC values of tested compounds were determined by visual inspection.

\subsection{Combination Effect}

The chemosensitizing activity of benzoxazole-type ligands and their metal complexes was determined based on the MIC values of the antibiotics in the presence of sub-inhibitory concentrations of the compounds ( $\left.\frac{1}{4} \mathrm{MIC}\right)$ in both Gram-negative and Gram-positive strains. The MICs were determined in strains by the two-fold broth microdilution method in 96-well plates, using serial dilutions of TET and CIP. The first four rows contained two-fold dilutions of antibiotics, and combinations of the TET and CIP and tested compounds were transferred into the last four rows. The $10^{-4}$ dilution of an overnight bacterial culture in $50 \mu \mathrm{L}$ of MHB was then measured to each well, except for the medium control wells. The plates were kept at $37^{\circ} \mathrm{C}$ for $18 \mathrm{~h}$. MIC values of antibiotics and their combination with tested compounds were detected by visual inspection. 


\subsection{Real-Time Accumulation Assay}

The accumulation of the efflux pump substrate EB was monitored by the automated EB method [26] using a LightCycler real-time thermocycler (LightCycler 1.5, Roche, Indianapolis, IN, USA). An aliquot of an overnight culture of the $S$. aureus strains in TSB medium was inoculated into fresh TSB medium, and it was incubated until it reached an optical density (OD) of 0.6 at $600 \mathrm{~nm}$. In the case of E. coli strains, the medium applied in the assay was LB broth; the preparation of the inoculum was similar to the one of $S$. aureus. The cells were washed with phosphate buffered saline (PBS; pH 7.4) and centrifuged at $13,000 \times g$ for $3 \mathrm{~min}$, the pellets were re-suspended in PBS ( $\mathrm{pH} 7.4$ ), and the OD was calibrated to 0.6 at $600 \mathrm{~nm}$. The compounds were measured at $\frac{1}{4} \mathrm{MIC}$ concentration (in double-concentrated form) to the EB solution in PBS. The final concentration of EB was determined according to the MIC and the fluorescent signal produced by this amount of EB. In the case of all strains, the concentration of EB was $1 \mu \mathrm{g} / \mathrm{mL}$. Then, $10 \mu \mathrm{L}$ of the EB solution plus the compound were pipetted into standard glass capillary tubes of $20 \mu \mathrm{L}$ maximum volume (Roche, Indianapolis, USA), and $10 \mu \mathrm{L}$ of bacterial culture (OD of 0.6 at $600 \mathrm{~nm}$ ) were transferred to the capillaries. The capillaries containing the samples were placed into the carousel, and the fluorescence was monitored at the FL-2 channel in every minute on a real-time basis.

Based on the data obtained, the relative fluorescence index (RFI) of the last time point (minute 30) was determined as follows:

$$
\mathrm{RFI}=\left(\mathrm{RF}_{\text {treated }}-\mathrm{RF}_{\text {untreated }}\right) / \mathrm{RF}_{\text {untreated }}
$$

where $\mathrm{RF}_{\text {treated }}$ is the relative fluorescence $(\mathrm{RF})$ at the last time point of the EB retention curve in the presence of an inhibitor, and $\mathrm{RF}_{\text {untreated }}$ is the relative fluorescence at the last time point of the EB retention curve of the untreated control having the solvent control (DMSO). VER was used as a positive control on MRSA strain and CPZ was used on Gram-negative and S. aureus ATCC strains.

\subsection{Anti-Biofilm Effect}

The biofilm production of the $S$. aureus ATCC 25923 strain was studied in 96-well plates using TSB broth in the presence of compounds. The overnight cultures were diluted to an OD of 0.1 at $600 \mathrm{~nm}$ and then measured to each well with the exception of the medium control wells, and compounds were pipetted individually at $\frac{1}{4}$ MIC concentration. The final volume was $200 \mu \mathrm{L}$ in each well. The samples were incubated at $30^{\circ} \mathrm{C}$ for $48 \mathrm{~h}$ with gentle agitation (100 rpm). Then, the medium was removed, and the plate was washed with tap water to discard unattached cells. $200 \mu \mathrm{L} \mathrm{CV}(0.1 \%$ [v/v]) was added to the wells and incubated for $15 \mathrm{~min}$ at room temperature. CV was removed from the wells and the plate was washed again with tap water. $200 \mu \mathrm{L} \mathrm{70 \%} \mathrm{ethanol} \mathrm{was} \mathrm{transferred} \mathrm{to} \mathrm{each} \mathrm{well} \mathrm{and} \mathrm{the}$ biofilm formation was determined by measuring the OD at $600 \mathrm{~nm}$ using Multiscan EX ELISA reader (Thermo Labsystems, Cheshire, CT, USA). The anti-biofilm effect of compounds was determined as the percentage (\%) of decrease in biofilm formation. The assay was repeated a minimum of three times. The results were calculated using a $t$-test and $p$-values of $<0.001$ were considered significant.

\subsection{Assay for Quorum Sensing Inhibition}

LB $^{*}$ was applied for these experiments. The sensor strain C. violaceum 026 and the AHL producer strains E. cloacae 31298 were inoculated as parallel lines and incubated at room temperature for $24-48 \mathrm{~h}$. The inhibition of bacterial communication was determined by the agar diffusion method. Filter paper discs (7.0 mm in diameter) were impregnated with $10 \mu \mathrm{L}$ of stock solutions $(1 \mathrm{mM})$ of the compounds in DMSO. The discs were placed between the parallel lines of the sensor and the AHL producer strains. The plates were kept at room temperature for another $24-48 \mathrm{~h}$, and the interactions between the strains and compounds were determined as the reduction in the size of the zone of purple pigment (violacein) production in millimeters [27]. PMZ was applied as a positive control. 


\subsection{Assay for Cytotoxic Effect}

The activity of increasing concentrations of the compounds on cell growth was determined in 96-well flat-bottomed microtiter plates by two-fold serial dilutions of the benzoxazole derivatives. The adherent human embryonic lung fibroblast cells $\left(10^{4} /\right.$ well) was seeded in EMEM medium in 96-well microtiter plates for $4 \mathrm{~h}$ prior to the assay. The serial dilutions of the compounds were made in a separate plate, and then pipetted to the plates containing the MRC- 5 cell line. Culture plates were incubated at $37^{\circ} \mathrm{C}$ for $24 \mathrm{~h}$; at the end of the incubation period, $20 \mu \mathrm{L}$ of MTT (3-(4,5-dimethylthiazol-2-yl)-2,5-diphenyltetrazolium bromide) solution (from a $5 \mathrm{mg} / \mathrm{mL}$ stock solution) was measured to each well. After the incubation at $37^{\circ} \mathrm{C}$ for $4 \mathrm{~h}, 100 \mu \mathrm{L}$ of sodium dodecyl sulfate (SDS) solution (10\% SDS in $0.01 \mathrm{M} \mathrm{HCl}$ ) was added to each well to dissolve the formazan crystals and the samples were further incubated at $37^{\circ} \mathrm{C}$ overnight. Cell growth was calculated by measuring the OD at $540 \mathrm{~nm}$ (ref. $630 \mathrm{~nm}$ ) with a Multiscan EX ELISA reader. The cytotoxicity was expressed as $\mathrm{IC}_{50}$ values, defined as the inhibitory dose that reduces the growth of the cells exposed to the tested compounds by $50 \%$. $\mathrm{IC}_{50}$ values and the standard deviation (SD) of triplicate experiments were calculated by using GraphPad Prism software version 5.00 for Windows with nonlinear regression curve fit (GraphPad Software, San Diego, CA, USA; www.graphpad.com) where $\mathrm{IC}_{50}$ : 0-30, $\mathrm{IC}_{50}: 31-60, \mathrm{IC}_{50}: 61-100$, and $\mathrm{IC}_{50}>100 \mu \mathrm{M}$ represent strong, moderate, weak, and no cytotoxic effects, respectively.

\subsection{Statistical Analysis}

The values were given as the mean \pm SD determined for three replicates from three independent experiments. The analysis of data was performed using SigmaPlot for Windows Version 12.0 software (Systat Software Inc, San Jose, CA, USA), applying the two-tailed $t$-test.

\section{Conclusions}

It can be concluded that the 2-trifluoroacetonylbenzoxazole ligands and their metal complexes have various and potent antibacterial activities. Our findings are still preliminary because several issues should be analyzed and investigated in the future, e.g., in vivo stability of the complexes, their interaction with plasma proteins, toxicity on liver cells. However, these metal complexes could be potential and promising drug candidates applied alone or in combination with standard antibiotics in the treatment of infectious diseases caused by resistant bacteria.

Author Contributions: Conceptualization: G.S. and M.K.; methodology: A.K., G.W., R.S.; validation: G.S., M.K.; investigation: A.K., S.S., B.R., N.S., G.W., R.S.; resources: G.S.; data curation: A.K., S.S., N.S., G.W., R.S.; writing—original draft preparation: G.S., A.K., B.R.; writing—review and editing: J.M., H.S., E.T., R.S., M.K.; supervision: G.S., H.S., E.T., M.K.; funding acquisition: G.S. All authors have read and agreed to the published version of the manuscript.

Funding: This research was funded by the project GINOP-2.3.2-15-2016-00038 (Hungary). The study was supported by the Nation's Young Talent Scholarship (Nemzet Fiatal Tehetségeiért Ösztöndij).

Conflicts of Interest: The authors declare no conflict of interest.

\section{References}

1. CDC. Antibiotic Resistance Threats in the United States, 2019; Centers for Disease Control and Prevention: Atlanta, GA, USA, 2019; pp. 1-29. [CrossRef]

2. Blair, J.M.A.; Webber, M.A.; Baylay, A.J.; Ogbolu, D.O.; Piddock, L.J.V. Molecular mechanisms of antibiotic resistance. Nat. Rev. Microbiol. 2015, 13, 42-51. [CrossRef] [PubMed]

3. Blanco, P.; Hernando-Amado, S.; Reales-Calderon, J.A.; Corona, F.; Lira, F.; Alcalde-Rico, M.; Bernardini, A.; Sanchez, M.B.; Martinez, J.L. Bacterial multidrug efflux pumps: Much more than antibiotic resistance determinants. Microorganisms 2016, 4, 14. [CrossRef] [PubMed]

4. Reygaert, W.C. An overview of the antimicrobial resistance mechanisms of bacteria. AIMS Microbiol. 2018, 4, 482-501. [CrossRef] 
5. Wang-Kan, X.; Blair, J.M.A.; Chirullo, B.; Betts, J.; La Ragione, R.M.; Ivens, A.; Ricci, V.; Opperman, T.J.; Piddock, L.J.V. Lack of AcrB efflux function confers loss of virulence on Salmonella enterica serovar Typhimurium. mBio 2017, 8, e00968-17. [CrossRef]

6. Santos, A.L.S.D.; Galdino, A.C.M.; de Mello, T.P.; de Ramos, L.S.; Branquinha, M.H.; Bolognese, A.M.; Columbano Neto, J.; Roudbary, M. What are the advantages of living in a community? A microbial biofilm perspective! Mem. Inst. Oswaldo Cruz 2018, 113, e180212. [CrossRef] [PubMed]

7. Abisado, R.G.; Benomar, S.; Klaus, J.R.; Dandekar, A.A.; Chandler, J.R. Bacterial quorum sensing and microbial community interactions. mBio 2018, 9, e02331-17. [CrossRef]

8. Saxena, P.; Joshi, Y.; Rawat, K.; Bisht, R. Biofilms: Architecture, resistance, quorum sensing and control mechanisms. Indian J. Microbiol. 2019, 59, 3-12. [CrossRef]

9. Patra, M.; Gasser, G.; Metzler-Nolte, N. Small organometallic compounds as antibacterial agents. Dalton Trans. 2012, 41, 6350-6358. [CrossRef]

10. Barry, N.P.E.; Sadler, P.J. Exploration of the medical periodic table: Towards new targets. Chem. Commun. 2013, 49, 5106-5131. [CrossRef]

11. Prachayasittikul, V.; Prachayasittikul, V.; Prachayasittikul, S.; Ruchirawat, S. 8-Hydroxyquinolines: A review of their metal chelating properties and medicinal applications. Drug Des. Dev. Ther. 2013, 7, 1157-1178. [CrossRef]

12. Imramovsky, A.; Kozic, J.; Pesko, M.; Stolarikova, J.; Vinsova, J.; Kralova, K.; Jampilek, J. Synthesis and antimycobacterial and photosynthesis-inhibiting evaluation of 2-[(E)-2-substituted-ethenyl]-1,3-benzoxazoles. Sci. World J. 2014, 2014, 1-11. [CrossRef] [PubMed]

13. Zhang, W.; Liu, J.; Macho, J.M.; Jiang, X.; Xie, D.; Jiang, F.; Liu, W.; Fu, L. Design, synthesis and antimicrobial evaluation of novel benzoxazole derivatives. Eur. J. Med. Chem. 2017, 126, 7-14. [CrossRef] [PubMed]

14. Wells, G.; Berry, J.M.; Bradshaw, T.D.; Burger, A.M.; Seaton, A.; Wang, B.; Westwell, A.D.; Stevens, M.F.G. 4-substituted 4-hydroxycyclohexa-2,5-dien-1-ones with selective activities against colon and renal cancer cell lines. J. Med. Chem. 2003, 46, 532-541. [CrossRef] [PubMed]

15. Kawase, M.; Harada, H.; Saito, S.; Cui, J.; Tani, S. In vitro susceptibility of Helicobacter pylori to trifluoromethyl ketones. Bioorg. Med. Chem. Lett. 1999, 9, 193-194. [CrossRef]

16. Kawase, M.; Motohashi, N.; Sakagami,H.; Kanamoto, T.; Nakashima,H.; Ferenczy, L.; Wolfard, K.; Miskolci, C.; Molnár, J. Antimicrobial activity of trifluoromethyl ketones and their synergism with promethazine. Int. J. Antimicrob. Agents 2001, 18, 161-165. [CrossRef]

17. Zoltan, V.; Armada, A.; Cerca, P.; Amaral, L.; Savka, M.A.; Szegedi, E.; Kawase, M.; Motohashi, N.; Molnár, J. Inhibition of quorum sensing and efflux pump system by trifluoromethyl ketone proton pump inhibitors. In Vivo 2012, 26, 277-289.

18. Watanabe, G.; Sekiya, H.; Tamai, E.; Saijo, R.; Uno, H.; Mori, S.; Tanaka, T.; Maki, J.; Kawase, M. Synthesis and antimicrobial activity of 2-trifluoroacetonylbenzoxazole ligands and their metal complexes. Chem. Pharm. Bull. 2018, 66, 732-740. [CrossRef]

19. Spengler, G.; Kincses, A.; Rácz, B.; Varga, B.; Watanabe, G.; Saijo, R.; Sekiya, H.; Tamai, E.; Maki, J.; Molnár, J.; et al. Benzoxazole-based $\mathrm{Zn}(\mathrm{II})$ and $\mathrm{Cu}(\mathrm{II})$ complexes overcome multidrug-resistance in cancer. Anticancer Res. 2018, 38, 6181-6187. [CrossRef]

20. Frei, A.; Zuegg, J.; Elliott, A.G.; Baker, M.; Braese, S.; Brown, C.; Chen, F.; Dowson, C.G.; Dujardin, G.; Jung, N.; et al. Metal complexes as a promising source for new antibiotics. Chem. Sci. 2020, 11, 2627-2639. [CrossRef]

21. Mouwakeh, A.; Kincses, A.; Nové, M.; Mosolygó, T.; Mohácsi-Farkas, C.; Kiskó, G.; Spengler, G. Nigella sativa essential oil and its bioactive compounds as resistance modifiers against Staphylococcus aureus. Phytother. Res. 2019, 33, 1010-1018. [CrossRef]

22. Hunoor, R.S.; Patil, B.R.; Badiger, D.S.; Vadavi, R.S.; Gudasi, K.B. 2D HETCOR studies of 1,2-dihydroquinazolinone derivative: Synthesis, characterization and anti-microbial study of its transition metal complexes. Pharm. Chem. 2010, 2, 116-128.

23. Alaudeen, M.; Sushama, P.G.; Dorothy, A.M. Synthesis and spectroscopic investigation of metal chelates of hydrazo pyrazolone derivative. Asian J. Chem. 2007, 19, 3403-3411.

24. Gajdács, M. Multidrug Resistance Reversing Activity of Organoselenium Compounds. Ph.D Thesis, University of Szeged, Szeged, Hungary, 2018. 
25. CLSI. Susceptibility Testing Process. In Methods for Dilution Antimicrobial Susceptibility Tests for Bacteria that Grow Aerobically, 10th ed.; Christopher, P.J., Polgar, E.P., Eds.; Clinical and Laboratory Standards Institute: Wayne, MI, USA, 2015; Volume 32, pp. 15-19.

26. Viveiros, M.; Martins, A.; Paixão, L.; Rodrigues, L.; Martins, M.; Couto, I.; Fähnrich, E.; Kern, W.V.; Amaral, L. Demonstration of intrinsic efflux activity of E. coli K-12 AG100 by an automated ethidium bromide method. Int. J. Antimicrob. Agents 2008, 31, 458-462. [CrossRef] [PubMed]

27. Varga, Z.G.; Szabó, M.A.; Schelz, Z.; Szegedi, E.; Amaral, L.; Molnar, J. Quorum sensing inhibition by phenothiazines and related compounds. Lett. Drug Des. Discov. 2011, 8, 133-137. [CrossRef]

(C) 2020 by the authors. Licensee MDPI, Basel, Switzerland. This article is an open access article distributed under the terms and conditions of the Creative Commons Attribution (CC BY) license (http://creativecommons.org/licenses/by/4.0/). 